\title{
Trends and Reliance on Foreign Labourers in Malaysia: Conventional Construction versus Industrialized Building System Construction
}

\author{
M.A.O Mydin ${ }^{1, a}$, N.R. Buyung ${ }^{2}$, N. Md. Sani ${ }^{3}$, N.F. Abas ${ }^{4}$ \\ ${ }^{1,2,3,4}$ School of Housing, Building and Planning, Universiti Sains Malaysia, 11800, Penang, Malaysia
}

\begin{abstract}
There has been an influx of foreign labourers in Malaysia over the past decade due to sustained economic growth and a limited labour market. As a long term measure to ensure sustainable growth as well as to minimize socio-economic implications, a medium to longer-term policy on foreign workers will be devised with the goal of reducing overdependence on foreign workers while attracting more skilled and trained professionals. In order to reduce the number of foreign workers, the government has encouraged the implementation of an IBS. An Industrialized Building System (IBS) is a construction system in which the components are manufactured in a factory, on or off site, positioned, and assembled into complete structures with minimal additional site work. This research has been carried out to discover trends, whether decreasing or increasing, in the employment of foreign labour in the Malaysian construction industry with reference to the Immigration Department of Malaysia. Additionally, interviews with construction labourers at IBS sites and conventional sites were carried out to identify the number of foreign labourers that are used in such projects.
\end{abstract}

\section{Introduction}

The construction industry has been undergoing changes due to the use of current technology which indirectly improves the quality and safety of buildings [1]. This has contributed to the usage of an Industrialized Building System (IBS) to solve the problems that occur at construction sites in Malaysia [2]. An Industrialized Building System (IBS) is a construction process that utilises techniques, products, components, or building systems which involve prefabricated components and on-site installation. There are five main IBS groups identified as being used in Malaysia which are precast concrete framing, panel and box systems, steel formwork systems, steel framing systems, prefabricated timber framing systems and block work systems[3]. The usage of these IBS types has had a positive impact on the construction industry. These systems assure valuable benefits such as reduction of unskilled labourers, less wastage, a reduced volume of building materials, increased environmental and construction site cleanliness, and better quality control [4].

In order to reduce the dependency on foreign labour in the local construction industry, CIDB strongly supports the use of labour-reducing systems or IBSs [5]. Dependency on foreign labourers brings numerous negative impacts to the nation within social and cultural contexts. It also increases

\footnotetext{
${ }^{\text {a }}$ Corresponding author : azree@usm.my
} 
the outflow of Ringgit to foreign economies because their money is ultimately transferred back to their own country. Numerous parties have organized programmes to educate the industry on the various benefits of IBS [6]. CIDB has organized large funds for researchers, standards development and also various training and promotion programmes in order to enhance the global competitiveness of Malaysian contractors. CIDB has also sponsored numerous Research and Development (R\&D) programmes to develop innovative IBS applications. Workers are not only being trained in the basics of conventional construction methods, but also in the installation of IBS components and IBS site management [7].

Many Malaysian citizens do not want to work in the construction sector which is considered to be one of the 3D's contributing to the country's dependency on foreign labour. They have no interest in working in rough nature of the sector, such as on construction sites that require them to exert more physical strength than working in an office where it is not hot, but rather a nice, conditioned environment. Additionally, they are too demanding when making job decisions and they believe that better qualifications will get a better job. Malaysian construction companies face several problems caused by the employment of foreign labour [8]. Firstly, accepting more productive and modern methods of construction is a low priority. This is coupled by the availability of cheap foreign labour and employing foreign labour is cheaper in comparison to employing local labour [9]. However, employing foreign labour will cause low productivity and poor quality of work because many of these foreign labourers do not have enough construction experience and they also lack necessary skills. Furthermore, communication barriers between the employers and foreign labours may lead to misunderstandings which can lead to a decrease in the quality and amount of work accomplished on a project [10].

\section{Methodology}

The statistics on foreign labour have been used in this analysis to observe the trends of foreign labour in the Malaysian construction sector from the year 2000 until the year 2013 (March). Survey research was also used to get more information for this research. The survey was done at the selected IBS and conventional sites to get information on the usage of foreign labour on construction sites. Data collection for this research was divided into primary data and secondary data. The primary data were collected by doing some interviews with those involved on construction sites such as the project manager, site supervisor, site engineer, and others at both IBS and conventional sites. The interviews were conducted to get data on the total number of labourers used at each site and their nationalities. These interviews were also conducted to achieve the second objective of the research. Meanwhile, secondary data were collected from the Immigration Department of Malaysia. This secondary data were taken to achieve the first objective of this research, to determine the trends of foreign labour in the Malaysian construction industry from the year 2000 until the year 2013 (March). Then, further investigation looked at the number of foreign labourers to determine whether the trend increased, decreased, or fluctuated from year to year.

\section{Results and Discussion}

\subsection{Number of Foreign Workers in the Malaysian Construction Sector}

Figure 1 shows the number of employed foreign labourers in the construction sector. This shows that the number of foreign labourers from the years 2000 to 2013 fluctuated. Taking a closer look at this trend, in 2001 the total number decreased, and then from 2001 until 2003, the number of foreign labourers increased significantly, to about 74\%, and dropped to 231,184 workers in 2004 .

From that point, the number of foreign labourers increased from 231,184 in 2004 to 281,780 in 2005 , before dropping to 267,809 in the year 2006. The number increased proportionally from 2006 until 2008, a growth of about 12\%, and decreased again between 2008 and 2011, before climbing 
slightly by about 2,866 persons in 2012 . However, this number shows dramatically increases about $210 \%$ in March 2013.

The foreign workers considered in the research were not illegal foreign workers and this number includes those workers who had gone through the 6P whitening program. The $6 \mathrm{P}$ whitening program includes Registration (Pendaftaran), Whitening (Pemutihan), Forgiveness (Pengampunan), Monitoring (Pemantauan), Enforcement (Penguatkuasaan) and Expulsion (Pengusiran).

Overall, it can be seen that the number of foreign workers in the Malaysian construction sector is uncertain because of continuous fluctuation. There have been years where the number of foreign workers decreased and there are also years in which numbers increased. Drastic increases in 2013 (March) suggest that the current demand for foreign labour in the industry is increasing. Moreover, it should be noted that this figure only shows registered foreign workers and does not include those working in Malaysia illegally. This figure would likely increase if the number of illegal foreign workers were known.

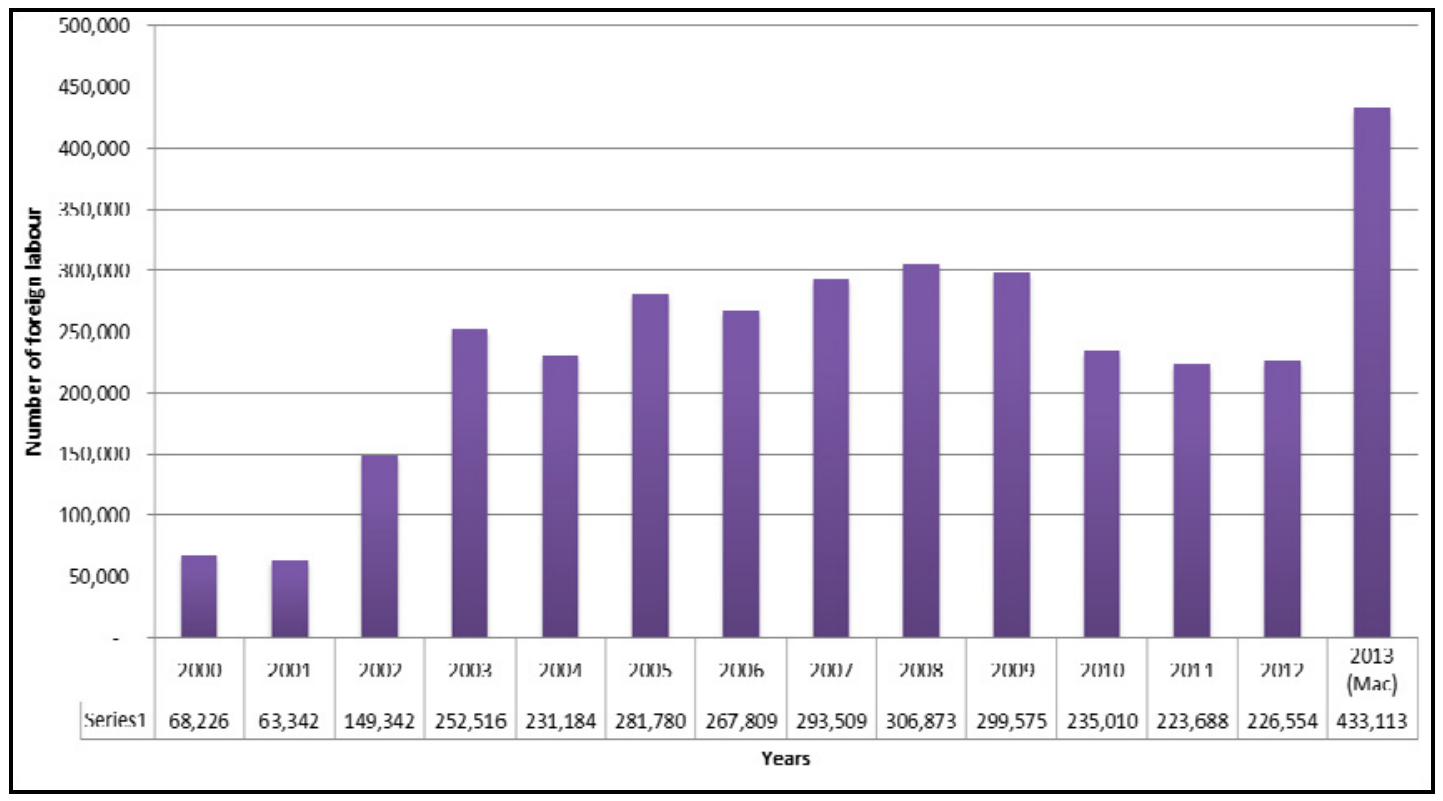

Fig 1: Number of employed foreign labourers in the construction sector Source: Immigration Department of Malaysia

\subsection{Comparison of the Number of Labourers in IBS Based Projects and Conventional Projects}

The comparisons drawn in Figure 1 portray project values ranging between RM50 million to RM60 million. Figure 2 shows how the conventional system use more foreign workers across all work subdivisions including structural works, architectural works, mechanical and electrical works, as well as infrastructure works. There are large differences between IBS projects (formwork and precast) and conventional system projects in terms of the usage of workers in structural works, where $57.7 \%$ of the total structural workers were involved in conventional projects, another $29.2 \%$ were in formwork projects and $16.7 \%$ were in precast projects. The category of architectural works also shows large differences in the usage of workers. $50 \%$ of the total workers in architectural works were from a conventional system, followed by a formwork system which was $27 \%$, and a precast system at $23 \%$. While, in mechanical and electrical works it can be seen the difference in the usage of workers was not as large as that of structural and architectural works. However, conventional systems still used a high number of workers compared to formwork systems and precast systems. According to this project value range it can be understood that conventional systems use more workers compared to IBS systems (formwork systems and precast systems). 


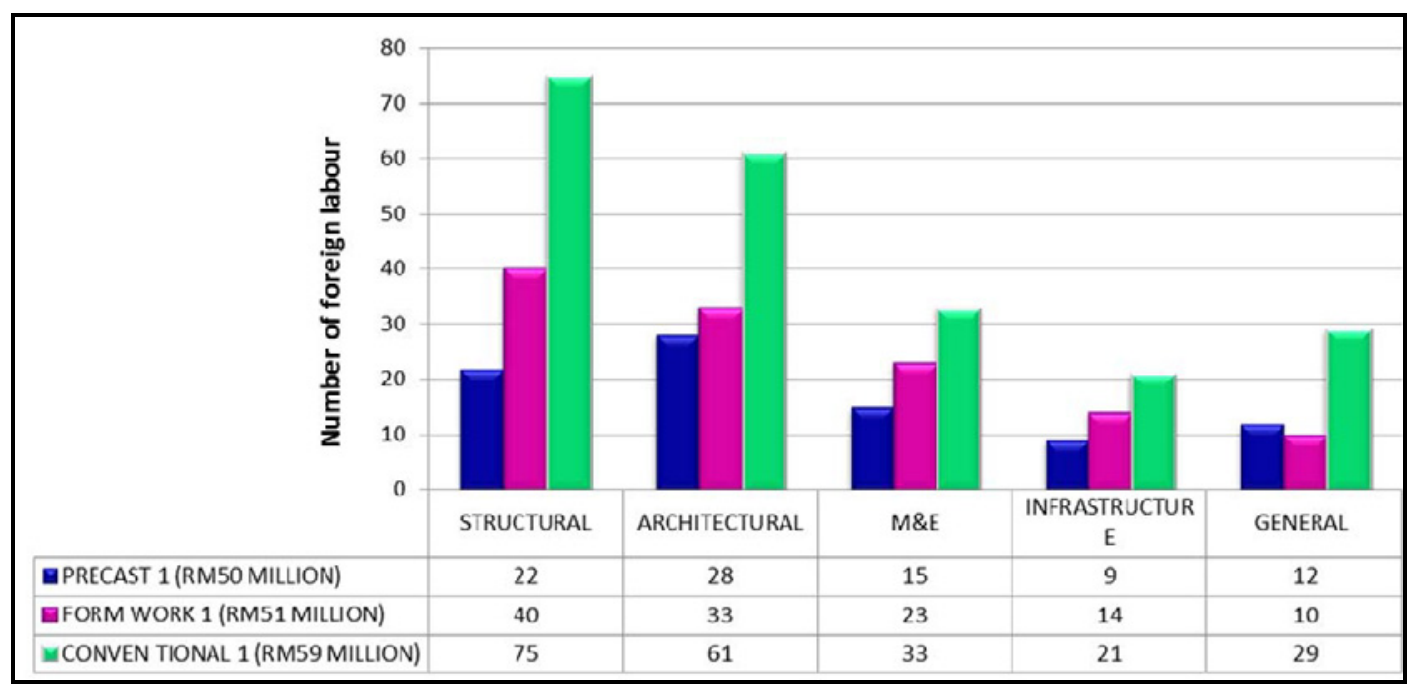

Fig 2: Number of employed foreign workers in construction for a project value of RM50-60 million

As the value of a project increases, so does the number of workers. This is demonstrated in Figure 2 with a project value range of RM55 million to RM65 million. Within this project value range it can also be understood that conventional systems used more workers compared to IBS systems (formwork and precast). Even though in structural works, conventional systems showed a higher usage of workers, the differences were not significant compared to the project value range of RM50 million to RM60 million.

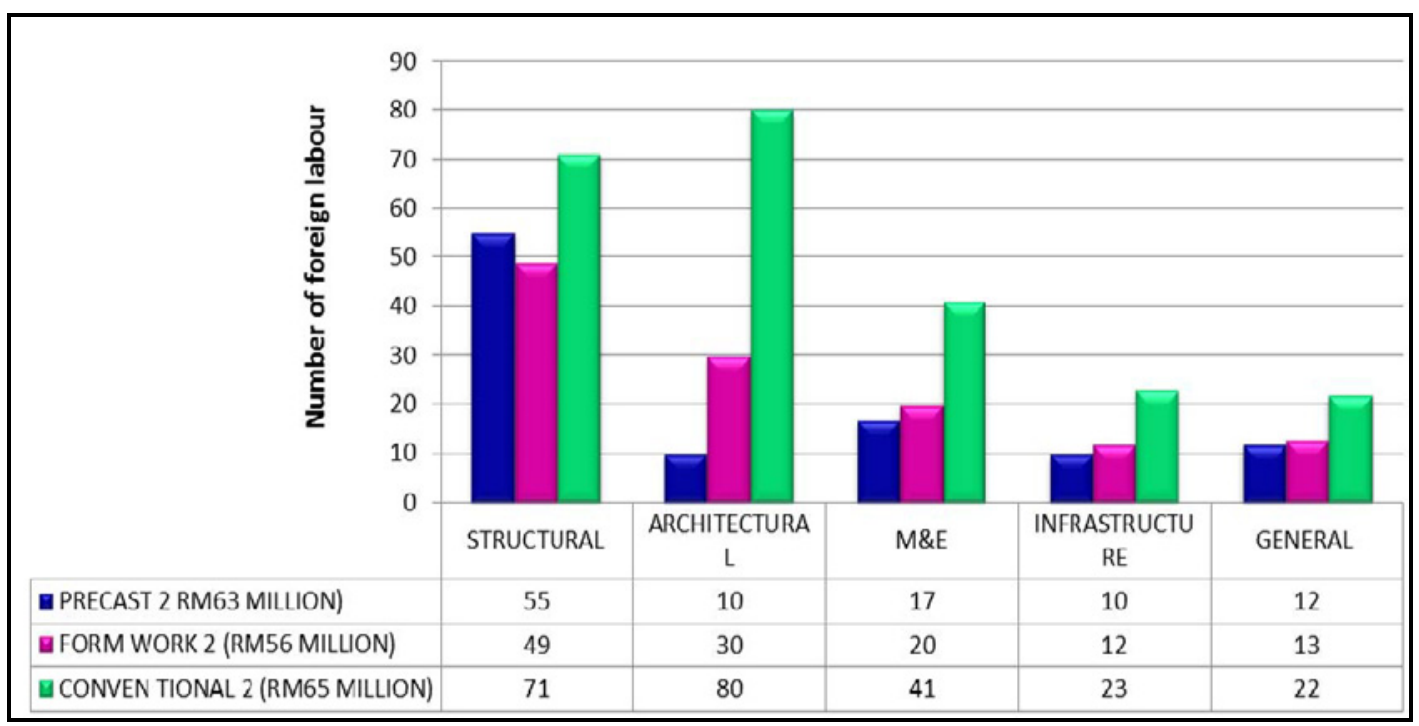

Fig 3: Number of employed foreign labourers in construction for a project value of RM55-65 million

However, in the architectural works category there are large differences in the usage of workers, with $66.7 \%$ of the total workers in architectural works coming from the conventional system. This is followed by formwork systems which used $25 \%$ of the total workers in architectural works. Precast systems showed the lowest usage of workers in architectural works at only $8.3 \%$. In this project value range, mechanical and electrical works in the conventional system also showed large differences in the usage of workers. From these values, it is clear that, in this project value range, conventional systems employ the highest number of foreign workers on construction sites. 


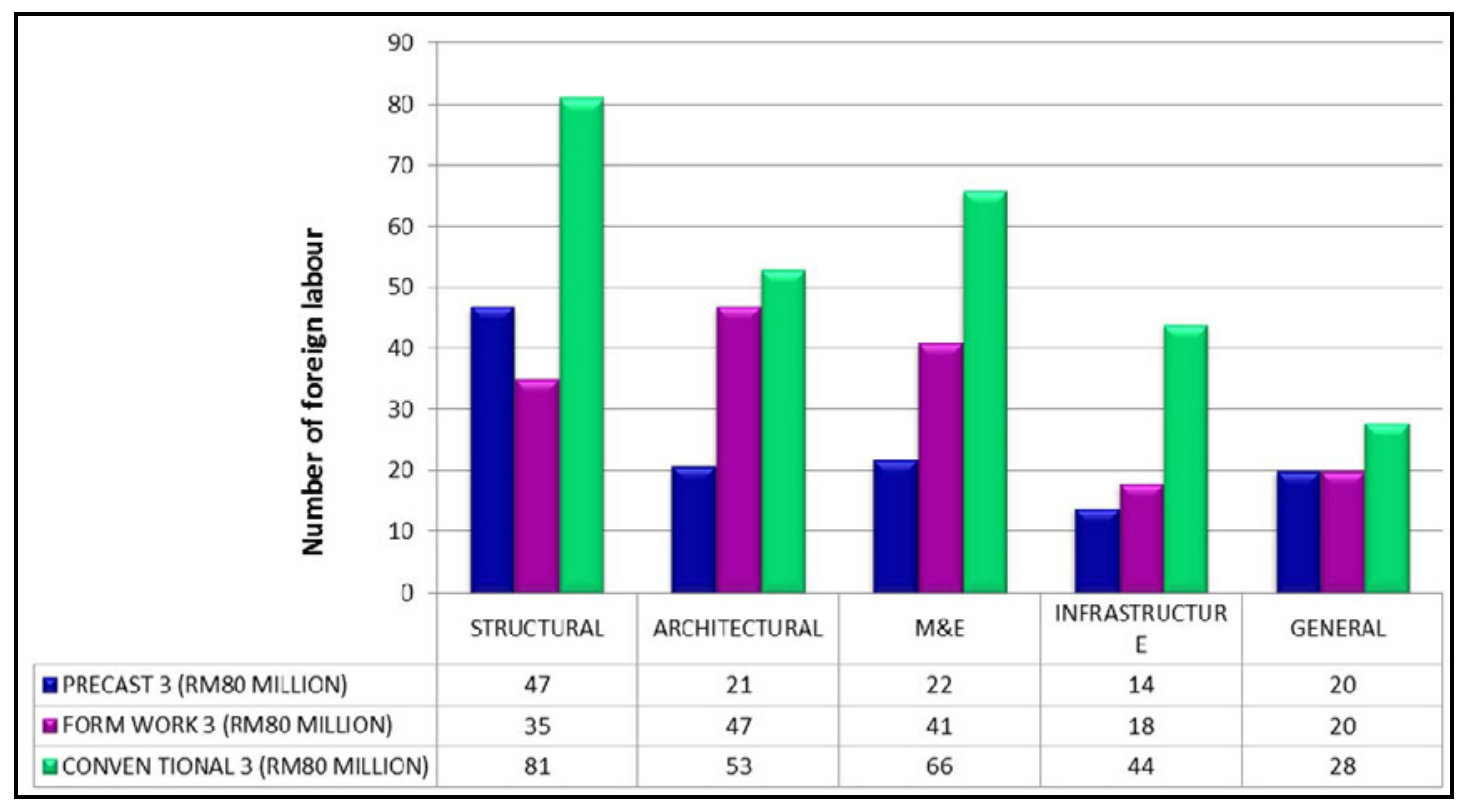

Fig 4: Number of employed foreign labourers in construction for a project value of RM80 million

This final comparison is for a project value of RM80 million. As shown in Figure 3, the conventional system again used more workers when compared with the IBS system. In can be seen in structural works that almost $50 \%$ of the workers were from a conventional system, followed by $29 \%$ from a precast system, and a formwork system accounted for $21 \%$ of the total workers in structural works. In this comparison, it is also evident that, for architectural works, there are large differences for precast systems, where the number is less than formworks systems and conventional systems. From a total of 121 workers in architectural works, only $17.4 \%$ were from a precast system. Meanwhile, formwork systems used $38.8 \%$ of the total workers in architectural works with conventional systems accounting for $43.8 \%$ of workers. This project value produced similar results as the RM50 million to RM60 million range and the RM55million to RM65 million range; conventional systems still proved to have the highest usage of foreign workers on construction sites.

For an overall comparison, it is clear that conventional systems required a higher number of workers on construction sites compared to IBS construction sites. With support from the case study interviews, it was proven that IBS systems can reduce the overall usage of labour on construction sites.

Table 1 shows the comparison between IBS based projects and conventional projects from based on the interviews conducted. The ratio shows the number of workers needed based on the project value measured in millions. For the precast system, the ratio for a project value of RM50 million was 1:1.72, for a project value of RM63 million the ratio was 1:1.65 and for a value of RM80 million the ratio was $1: 1.55$. This means for every one million of the project value these projects used $1.72,1.65$ and 1.55 workers. If the number is adjusted and rounded off, it comes to two (2) workers for every one million of the project value. This means projects that used a precast system only needed two (2) workers for every one million of the project value.

Meanwhile, for projects that used formwork systems the ratio for a project value of RM51 million was 1:2.35, RM56 million was $1: 2.11$ and RM80 million was $1: 2.01$. This is also indicates that for every one million of the project value this system will use 2.35, 2.11 and 2.01 workers. If this number is rounded of, it also comes to two (2) workers that will be used for every one million of the value of the project. 
For conventional projects, the ratio for a project value of RM59 million was 1:3.71, RM65 million was 1:65 and RM80 million was 1:3.40. By rounding these figures off, this suggests three (3) or four (4) workers will be used in conventional projects for each one million of the project value.

Table 1: Comparison between IBS based projects and conventional projects

\begin{tabular}{|c|c|c|c|c|c|c|c|c|c|c|}
\hline & OJECT & $\begin{array}{c}\text { PRECAST } \\
1\end{array}$ & $\begin{array}{c}\text { PRECAST } \\
2\end{array}$ & $\begin{array}{c}\text { PRECAST } \\
3\end{array}$ & $\begin{array}{c}\text { FORM } \\
\text { WORK 1 }\end{array}$ & $\begin{array}{c}\text { FORM } \\
\text { WORK } 2\end{array}$ & $\begin{array}{c}\text { FORM } \\
\text { WORK } 3\end{array}$ & $\begin{array}{c}\text { CONVEN } \\
\text { TIONAL }\end{array}$ & $\begin{array}{c}\text { CONVEN } \\
\text { TIONAL }\end{array}$ & $\begin{array}{c}\text { CONVEN } \\
\text { TIONAL }\end{array}$ \\
\hline VALUE & M MILLION) & 50 & 63 & 80 & 51 & 56 & 80 & 59 & 65 & 80 \\
\hline & STRUCTURAL & 22 & 55 & 47 & 40 & 49 & 35 & 75 & 71 & 81 \\
\hline & ARCHITECTURAI & 28 & 10 & 21 & 33 & 30 & 47 & 61 & 80 & 53 \\
\hline & M\&E & 15 & 17 & 22 & 23 & 20 & 41 & 33 & 41 & 66 \\
\hline LABOUR & NFRASTRUCTURH & 9 & 10 & 14 & 14 & 12 & 18 & 21 & 23 & 44 \\
\hline & GENERAL & 12 & 12 & 20 & 10 & 13 & 20 & 29 & 22 & 28 \\
\hline & TOTAL & 86 & 104 & 124 & 120 & 124 & 161 & 219 & 237 & 272 \\
\hline & RATIO & 1.72 & 1.65 & 1.55 & 2.35 & 2.11 & 2.01 & 3.71 & 3.65 & 3.40 \\
\hline
\end{tabular}

The ratio shows that IBS based projects (precast and formwork) use less workers compared to conventional projects per one million of the project value. The differences in the ratios between IBS based projects and conventional projects also show that the use of IBS systems can reduce the number of labour at construction sites, while double the number of workers needed on IBS based projects is required for conventional projects. This shows a large difference in terms of labour usage on IBS based projects and conventional projects.

\subsection{Labour Composition Based on Nationality}

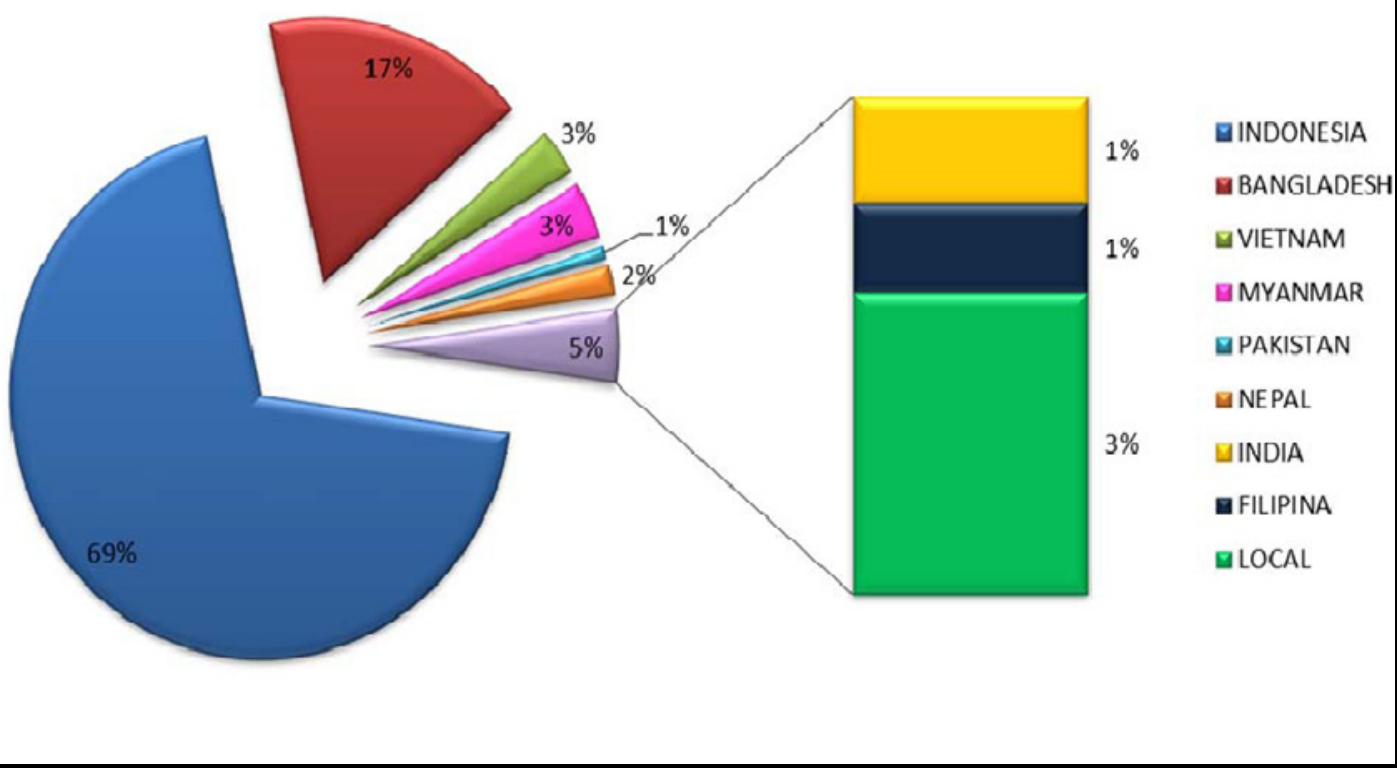

Fig 5: Labour composition based on nationality

Figure 5 shows the breakdown of workers' nationalities on the construction sites where interviews were conducted. It can be seen that the majority of the workers were from Indonesia, accounting for more than half, or $69 \%$, of the total workers. This was followed by workers from 
Bangladesh, accounting for $17 \%$ of the on-site labour. The large difference in percentage between workers from Indonesia and Bangladesh was about 52\%. Ranking next, workers from Vietnam and Myanmar both accounted for 3\% of the total workers. Workers from Nepal comprised $2 \%$ of the total workers while workers from Pakistan, India and the Philippines, respectively, accounted for $1 \%$.

Although IBS construction sites showed a reduction in the number of labourers being used, these sites still used foreign labour instead of local labour. Based on the IBS Roadmap 2003-2010, the planned positive impact of the new, purpose-based government incentives for using IBS was to reduce the wet-trades on sites and reduce dependency on foreign labour. However, such a positive impact could not be seen in the projects selected for this study. This was made evident as the majority of the labour on the studied IBS based projects was foreign labour, most of which was from Indonesia. The use of local labour was minimal on IBS based projects while no local labour was used in conventional based projects.

\section{Conclusion}

The results of this study show the number of foreign labourers in Malaysia's construction industry to be unpredictable. In certain years, the amount of foreign labour increased and then declined in the following years. However, the number of foreign labourers in 2013 (March) showed a huge increase compared with the previous years' reported fluctuations. The fact that this trend is occurring suggests that, even though IBS systems have been implemented for a considerable period of time, the demand for foreign labour in the construction sector still remains high. Although the number of foreign labourers decreased in certain years, the overall trend shows that numbers have been growing over the past 13 years, highlighting the fact that the Malaysian construction industry is still heavily dependent on foreign labour for construction-related work. This was exemplified by findings that revealed even IBS construction sites used foreign labour instead of local labour. IBS systems should focus on the utilization of local labour as mentioned in the IBS Roadmap 2003-2010, which promotes the goal of reducing the wet-trades in order to reduce the dependency on foreign labour in Malaysia. Hence, all parties should be responsible for ensuring that the goal of IBS systems can be achieved.

\section{Acknowledgement}

The authors would like to thank the funding bodies of this research: Universiti Sains Malaysia under USM Short Term Grant. No. 304/PPBGN/6312147

\section{References}

1. Laws of Malaysia (2006), Act 265, Employment Act 1955

2. M.A. Othuman Mydin, N. Md Sani, M. Taib, N. Mohd Alias, " Imperative Causes of Delays in Construction Projects from Developers' Outlook," MATEC Web Of Conferences, Volume 10, 06005

3. Construction Industry Development Board (CIDB) (2003), Industrialised Building System (IBS) Roadmap 2003-2010, Kuala Lumpur

4. S.W. Tan, M.A. Othuman Mydin, N. Md Sani, M.Z. Sulieman, "Investigation into Common Decay of Educational Buildings in Malaysia," MATEC Web Of Conferences, Volume 10, 05001

5. Mohd Arif Marhani, Hamimah Adnan, Har Einur Baharuddin, Mohd Reza Esa, Ahmad Arzlee Hassan. (2012), "Dependency of Foreign Workers in Malaysian Construction Industry", Built Environment Journal, Vol. 9, No. 1, 39-50 
6. M.A. Othuman Mydin, N. Md Sani, A.F. Phius, "Investigation of Industrialised Building System Performance in Comparison to Conventional Construction Method," MATEC Web Of Conferences, Volume 10, 04001

7. Construction Industry Development Board (2009), CIDB Annual Report, Strategic Trust 5

8. Grace Dairiam (2006), Country Case Studies on Bilateral Labour Agreements - Malaysia

9. M.A. Othuman Mydin, N. Md Sani, M. Taib, " Industrialised Building System in Malaysia: A Review," MATEC Web Of Conferences, Volume 10, 01002

10. Construction Industry Development Board (CIDB)(2003), Survey on the Usage of Industrialised Building Systems (IBS) in Malaysian Construction Industry, IBS Survey 